\title{
What Sparks Ethical Decision Making? The Interplay Between Moral Intuition and Moral Reasoning: Lessons from the Scholastic Doctrine
}

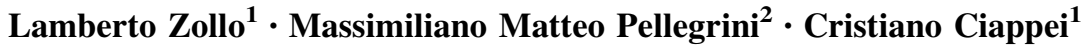

Received: 20 July 2015/ Accepted: 17 May 2016

(C) Springer Science+Business Media Dordrecht 2016

\begin{abstract}
Recent theories on cognitive science have stressed the significance of moral intuition as a counter to and complementary part of moral reasoning in decision making. Thus, the aim of this paper is to create an integrated framework that can account for both intuitive and reflective cognitive processes, in order to explore the antecedents of ethical decision making. To do that, we build on Scholasticism, an important medieval school of thought from which descends the main pillars of the modern Catholic social doctrine. Particularly, the focus will be on the scholastic concept of synderesis, which is an innate human faculty that constantly inclines decision makers toward universal moral principles. Managerial implications are discussed, stressing how a rediscovery of decision makers' intuitive moral judgments could be relevant in the reflective thinking practice of managers' ethical reasoning, thus saving them from rational insensitivity to ethical dilemmas.
\end{abstract}

Keywords Ethical decision making $\cdot$ Dual processing theory $\cdot$ Intuition $\cdot$ Emotion $\cdot$ Cognition $\cdot$ Synderesis

Lamberto Zollo

lamberto.zollo@unifi.it

Massimiliano Matteo Pellegrini

dr.massimiliano.pellegrini@gmail.com

Cristiano Ciappei

cristiano.ciappei@unifi.it

1 Department of Sciences for Economics and Business, University of Florence, Via delle Pandette, 9, 50127 Florence, Italy

2 Claude Littner Business School, University of West London, Boston Manor Road, Brentford, London TW8 9GA, UK

\section{Introduction}

Following recent corporate scandals in the global economic scenario, research on ethical behavior has increasingly developed within the general area of business. In particular, ethical decision making has progressively gained relevance in the management literature (Tenbrunsel and SmithCrowe 2008). A comprehensive body of research has been produced, either with a theoretical or an empirical approach (for an extensive review of this subject see, for example, Craft 2013; Ford and Richardson 1994; O’Fallon and Butterfield 2005). A primary and central element of all this body of literature mainly remains a rationalist and cognitive approach, among which Rest's model of ethical decision making (1986) is one of the most cited specific frameworks. Building upon this, a variety of theoretically positive and descriptive models of ethical decision making have been proposed, all pointing to a predominance of rational processes (e.g., Ferrell and Gresham 1985; Hunt and Vitell 1986; Jones 1991; Treviño 1986). In such models, intuition and emotions are set apart or completely disregarded, and for this reason the rationalist approach seems to encounter limitations and shortfalls, especially in uncertain, unexpected, and dynamic contexts (Groves et al. 2008; Pellegrini and Ciappei 2015; Treviño et al. 2006). In such circumstances, decision makers rely heavily on their 'gut feelings,' emotions, and intuitive mental processes (Gaudine and Thorne 2001; Zhong 2011). For this reason, social psychologists and business scholars have recently rediscovered the importance of the emotive, instinctive, and intuitive reactions of decision makers (Dane and Pratt 2007; Haidt 2001), a claim that is traditionally supported by intuition-based models of human cognition (e.g., Evans 2008; Kahneman 2003; Stanovich and West 2000). Thus, it seems reasonable to say that these intuitive and emotional 
processes, which can be summarized in the expression moral intuition, deeply influence the decision maker in such contexts (Provis 2015). In contrast, conscious and rational processes, which can be summarized in the expression moral reasoning, in such situations may instead occur in a later phase to offer a 'rationale' or a 'sense' for behaviors and decisions undertaken (Haidt 2001).

Accordingly, the aim of this paper is to propose an integrated theoretical framework for ethical decision making that is able to take into a better account intuitive processes or moral intuition and how such processes can be blended into the traditional rational approach. Although a few scholars have tried to shed some light on this aspect, which is considered a pre-stage of the cognitive process (Dane and Sonenshein 2014; Marquardt and Hoeger 2009; Sinclair and Ashkanasy 2005), such a theme remains scarcely investigated. For this purpose, we specifically use the concept of synderesis, a significant element of the scholastic theory on human morality and conscience (Aquinas, 1265-1274; 1947; Bonaventure, 1259; 1956), a Catholic school of thought which has deeply influenced modern Christian social doctrine tradition (e.g., see Benedict XVI, On Conscience, 2007; Melé 2016). The concept refers to an innate human habit that fosters moral judgment and triggers the virtue of practical reason, as specified by recent managerial literature $(\mathrm{Ce}$ lano 2013; Das Neves and Melé 2013; Dierksmeier and Celano 2012).

Within this concept, we want to contribute to the traditional virtue ethics debate that has frequently addressed the problem of ethical decision making (Arjoon 2010; Bastons 2008; Melé 2010), but mainly with intrinsic assumptions of rationalist rationales (Kohlberg 1969; Rest 1986). Thus, the research enlarges the debate by deepening the role of synderesis in the instinctive, direct, and automatic formation of moral intuition and its outcomes, i.e., intuitive moral judgments, showing also why this approach is better than other possible explanations of the phenomenon. We propose an integrated framework of ethical decision making that blends the two traditionally opposed perspectives, i.e., intuitionism and a rational perspective, in order to better investigate the antecedents of the ethical decision-making stages and unpack the concept of moral intuition.

This work contributes to the literature in three ways. Firstly, it extends the traditional framework about ethical decision making by blending features of the rationalist and intuitionist approaches, as we stated above. Secondly, the research develops a theoretical model for moral intuition. Thirdly, it enriches the virtue ethics paradigm, thanks to the concept of synderesis, which allows for a simultaneous account of both intuitional and rational aspects of the ethical decision-making process, as explained later.
This study is composed of six sections including this introduction. In the second section, we illustrate and apply the dual processing theory of human cognition to ethical decision making, conceptualizing possible relationships between the rationalist and the intuitionist approaches. In the third section, we unpack the notion of moral intuition and illustrate its role in the ethical decision-making process. Next, we introduce the concept of synderesis, providing propositions about its influences on the overall ethical decision-making process. Finally, we discuss the main findings, managerial implications, and contributions of this paper, along with its limitations, and offer suggestions for future research.

\section{Ethical Decision Making: Traditional and Modern Approaches}

Ethical decision making refers to "a process by which individuals use their moral base to determine whether a certain issue is right or wrong" (Carlson et al. 2009, p. 536; see also Tenbrunsel and Smith-Crowe 2008). According to Jones (1991), the main elements that characterize such a process are moral issues and moral agents; a moral issue arises whenever an individual behavior may cause favorable or damaging consequences for others; a moral agent is an individual who acknowledges the presence of a moral issue and acts according to his/her morality. Business ethics scholars have increasingly studied the relationship between moral issues and moral agents in the ethical decision-making domain (Bastons 2008; Melé 2010; Morales-Sánchez and Cabello-Medina 2013). However, traditionally this problem has been tackled with an approach that the literature refers to as rationalist, while more recently, especially thanks to the emergence of psychological studies about human intuition (Dane and Sonenshein 2014; Haidt 2001; Kahneman and Frederick 2002), a new paradigm has developed, referred to as intuitionist.

\section{The Rationalist Tradition of Ethical Decision Making}

Traditionally, rational cognitive models (see, e.g., Kohlberg 1969; Rest 1986) have been thoroughly used in research on ethical decision making (Craft 2013; O'Fallon and Butterfield 2005). Particularly, Rest's four-component model represents an often used and mentioned tool to describe ethical decision making (Rest 1986; Rest and Narváez 1994). In this perspective, the ethical decisionmaking process begins with a phase of moral awareness, which is the recognition of a problem involving a moral issue. The act of acknowledging the existence of a moral 
issue represents the outset of the ethical decision-making process (Jones 1991; Lewis 1989). In this initial phase, the decision maker 'frames' possible decisions (Tversky and Kahneman 1986, p. 257), thus revealing his/her 'sensitivity' toward taking others and their welfare into account (Rest and Narváez 1994, p. 9). This phase is further divided into another two sub-processes; the first is the 'operating' process of the moral agent's cognition that thinks about possible actions; the second, the 'predicting' process, forms ideas about potential outcomes (Bastons 2008, p. 394). After a moral issue is acknowledged, the second phase of the process is moral judgment, when the decision maker formulates a moral judgment about the ethical dilemma, deciding what has to be considered as morally correct (Jones 1991). Specifically, in this phase the decision maker deliberates, so s/he assigns moral labels, such as 'good' and 'bad,' to possible actions (Melé 2010; Morales-Sánchez and Cabello-Medina 2013). Such a phase results in moral judgments that assume "the greatest importance in ethics" (Crossan et al. 2013, p. 570). Once the ethical situation has been morally judged, the next phase is moral intent. In this phase, the decision maker's cognition 'structures' possible actions according to his/her moral principles (Bastons 2008, p. 394). The moral agent decides how to act by prioritizing some moral values above others and being responsible for moral consequences (Craft 2013; Melé 2005). As a result, moral intent reveals the decision maker's willingness to implement an ethical behavior (Treviño et al. 2006). Finally, the fourth phase is moral behavior, which refers to implementing the ethical behavior according to the moral agent's intention (Craft 2013; Morales-Sánchez and Cabello-Medina 2013). According to Rest (1986, p. 15), moral behavior involves coping with impediments, difficulties, fatigue, and frustration. Hence, one of the main features of the moral behavior phase refers to the decision maker's persistence in implementing an ethical action (O'Fallon and Butterfield 2005).

Current positive models relying on Rest's framework interpret the ethical decision-making process as completely conscious and controlled by the individual (Crossan et al. 2013). In this way, the decision maker intentionally deliberates on moral dilemmas and makes a rational choice (Morales-Sánchez and Cabello-Medina 2013). What emerges is the predominant role of intentional, deliberate, and rational processes over ethical decision making (Haidt 2001; Weaver et al. 2014). For this reason, with different approaches, all these paradigms refer to a 'global' process of moral reasoning, whose function is "to rationalize and provide clear standards of rational justification for directives by which to live the moral life and evaluate the moral practices of individuals" (Buchholz and Rosenthal 2005, p. 308).
Some authors assert that the ultimate goal of moral reasoning is to re-evaluate the decision and then to provide moral justification for and legitimatization of the decision maker's behavior (Sonenshein 2007; Zhong 2011). Whatever is considered as the main purpose of moral reasoning, an evident call has been made to understand factors that may come before the traditional ethical decision-making stages or pre-existing conditions that may influence such stages (Craft 2013; O'Fallon and Butterfield 2005; Weaver et al. 2014). Three theories are particularly relevant in such a matter: the person-situation interactional framework (Treviño 1986), the social and environmental contingency models (Ferrell and Gresham 1985; Hunt and Vitell 1986), and the moral intensity factor (Jones 1991).

Firstly, Treviño's model (1986) focuses on two classes of factor: individual and situational. The former category refers to individual factors pertinent to the decision maker's "experience and circumstances of birth" (Ford and Richardson 1994, p. 206) such as age, education, employment, personality and values, and Machiavellianism (Craft 2013; O'Fallon and Butterfield 2005). The second category instead refers to particular "situational pressures" (Ford and Richardson 1994, p. 212) that may also affect the process. Situational factors include organization and industry characteristics, working group and managerial influences, and codes of conduct (O'Fallon and Butterfield 2005; Sonenshein 2007). These elements are external to the ethical decision-making process since they represent preconditions which the decision makers have to cope with. Ferrell and Gresham's model (1985) enlarges the set of contingencies that may affect the process, especially those related to the decision maker's socio-cultural environment (Jones 1991). Those contingencies include organizational elements such as norms, beliefs and values of social groups, labeled 'significant others,' and professional opportunities depending on corporate policy, rewards and punishments (Ferrell and Gresham 1985, pp. 90-92). Finally, Jones (1991) theorizes that the way decision makers respond to a particular moral issue depends on the characteristics of the moral issue itself-a characteristic called "moral intensity" (p. 372). Specifically, the perceived moral intensity of an issue raises the level of attention that the decision maker dedicates to the problem (O'Fallon and Butterfield 2005).

What emerges from such models is that both personal and environmental factors impact on decision makers' ability to recognize a moral issue, sharpening or hampering the whole ethical decision-making process (Hunt and Vitell 1986; Jones 1991). The whole discussion about the rational approaches of ethical decision making is synthesized in Fig. 1. 
Fig. 1 A comprehensive rational framework of ethical decision making

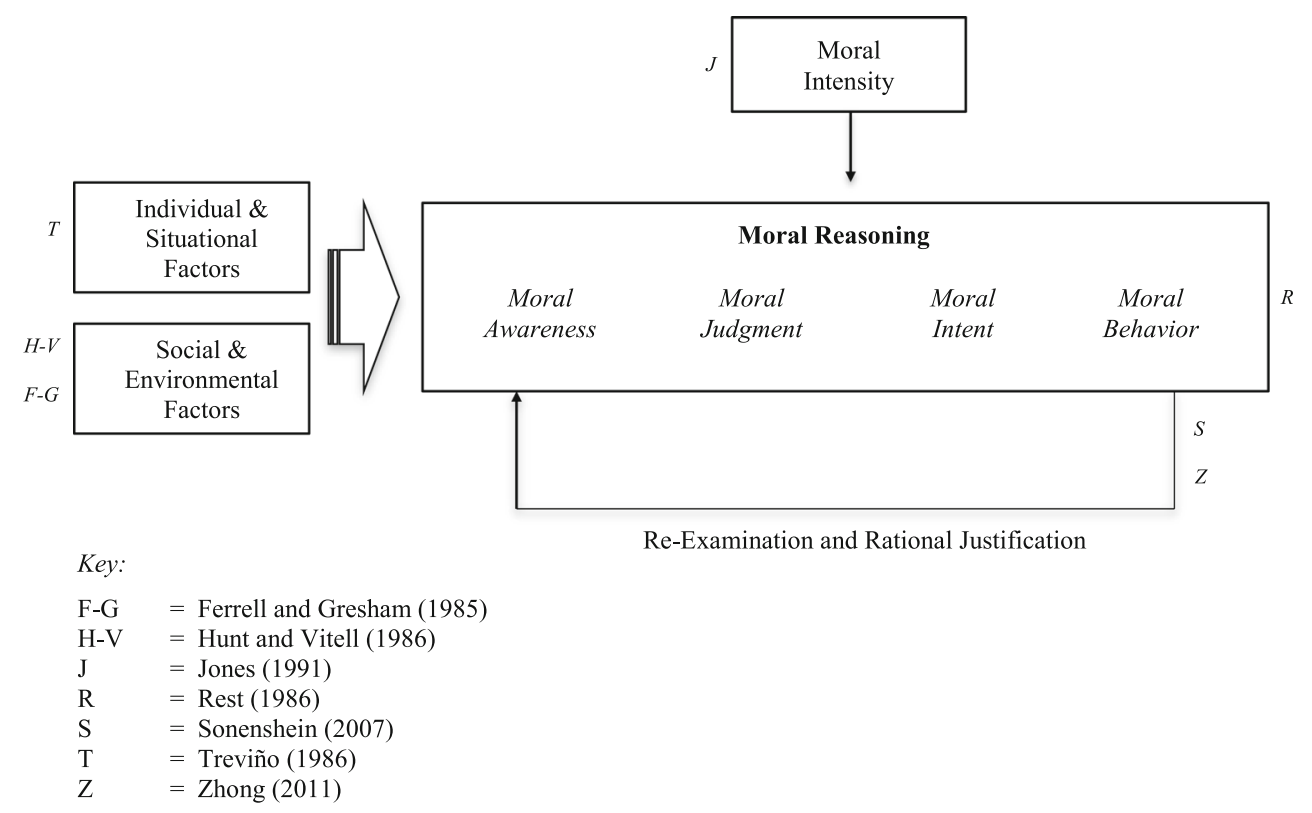

\section{Criticisms of the Rationalist Tradition: The Role of Moral Intuition in Ethical Decision Making}

This work follows the theoretical debate about components that precede the ethical decision-making framework (Craft 2013; O'Fallon and Butterfield 2005). The aim of this paper is to respond to this call by adopting an integrated framework where both the traditional and recent studies of social psychology (e.g., Haidt 2001, 2007; Haidt and Bjorklund 2008) serve such a purpose.

Modern psychology literature has started to question the assumption about rationality being the principal component of ethical decision making. Haidt's social intuitionist model $(2001,2003 a, 2007)$ represents one of the most prominent criticisms of the primacy of rationalist models, thanks to the emphasis on the concept of moral intuition. Such a concept is described as "the sudden appearance in consciousness of a moral judgment, including an affective valence (good-bad, like-dislike), without any conscious awareness of having gone through steps of searching, weighing evidence, or inferring a conclusion" (Haidt 2001, p. 818). Interestingly, the adjective 'affective' denotes the influence of an emotional process within the moral intuition construct. Despite both intuitions and emotions concurring in the formation of intuitive moral judgments (Haidt 2003b), the present research is focused on the process of intuiting while the discussion about emotions is only instrumental when considering such a theoretical analysis. Also, even if closely related, intuitions and emotions pertain to different spheres of the sensitive level in the decision-making process, respectively, the cognitive and appetitive ones (Kim and Johnson 2013; Wang and
Hackett 2015). In general, intuition may appear "at the fringe of consciousness" (Haidt and Bjorklund 2008, p. 188; see also Haidt and Joseph 2004), thus stressing the non-conscious, unintentional, and non-deliberative nature of moral intuition.

Particularly, Haidt's model (2001) can be included in the broader stream of research that adopts what is called the 'dual processing' theory of human cognition (Cushman et al. 2006; Evans 2008; Kahneman 2003; Stanovich and West 2000). Indeed, the modern psychological debate on moral judgment recognizes the traditional, 'consciousreasoning' perspective (Kohlberg 1969; Rest 1986) and, in contrast, the intuitionist perspective (Haidt 2001, 2007). According to the former, "people generate moral judgments by consciously reasoning over the principles they articulate in moral justifications," while the latter proposes that "moral judgments arise as intuitions generated by automatic cognitive processes, and that the primary role of conscious reasoning is not to generate moral judgments, but to provide a post hoc basis for a moral justification" (Cushman et al. 2006, p. 1082). As a result, moral reasoning is seen as a 'servant' of moral intuition, offering intentional deliberations and rational justification of something that is already present in the subconscious (Weaver et al. 2014, p. 104). The central claim of intuition theorists is that the moral judgment of decision makers is intuitive and may be more effective than rational information processing (Dane and Pratt 2007; Dane and Sonenshein 2014; Haidt 2001; Zhong 2011).

These claims replicate the dichotomy proposed by the theory of System 1 and System 2 (Evans 2008; Kahneman 2003; Kahneman and Frederick 2002; Stanovich and West 
2000), which individuates two distinct information processing systems. Actually, psychological scholars differentiate between the intuitive, reflexive, and automatic cognitive processes, named System 1-also referred to as the 'experiential system' (Epstein 1994, p. 710)—and the controlled, reflective, and analytic processes named System 2 (Evans 2008; Kahneman and Frederick 2002; Stanovich and West 2000). System 1 includes instinctive behaviors that are innately programmed in human cognition and is defined as rapid, parallel, and automatic in nature, while System 2 in contrast is described as slow, controlled, logical, and sequential in nature, thus resulting in the human powerful general purpose reasoning system (Evans 2008; Stanovich and West 2000). Stanovich (2008) recently labeled System 1 with the acronym TASS-'The Autonomous Set of Systems'-stressing that these processes "respond automatically to triggering stimuli; their execution is not dependent upon input from, nor is it under the control of, the analytic processing system (System 2); and finally TASS can sometimes execute and provide outputs that are in conflict with the results of a simultaneous computation being carried out by System 2" (p. 57). On the other hand, System 2 allows conscious information processing systems resulting in abstract, hypothetical, and algorithmic thinking (Evans 2008; Kahneman and Frederick 2002). Actually, these two distinct but simultaneous cognitive processes may be in conflict in particular circumstances; this is the case of instinctual behaviors that 'contrast' an assumption of complete rationality, such as "overeating, or smoking" (Evans 2008, p. 268). The opposite case is also true, where reflection and deliberation may rationally deviate the innate and intuitive ethical propensity of individuals, thus resulting in the 'unintended unethicality' of decision makers (Tenbrunsel and SmithCrowe 2008, p. 553; see also Palazzo et al. 2013). In line with this, integrated models of decision making theorize interactive and iterative relationships between the intuitive and rational processes, interpreted as parallel and complementary (Epstein 1994; Sinclair and Ashkanasy 2005). Such a perspective has recently been named the "spiraling process" in the ethical decision-making literature (Woiceshyn 2011, p. 312). Hence, the dual processing theory of human cognition theorizes the "two minds in one brain" approach (Evans 2008, p. 268), differentiating between the intuitive, automatic, effortless, and unintentional processes, called System 1, and the reasoned, deliberative, effortful, and intentional processes, called System 2 (Kahneman 2003; Stanovich and West 2000).

Particularly referring to the dual processing theory of social judgment, Evans (2008) recently argued that "Intuitive judgments seem to have the System 1 characteristics, whereas reflective decision making seems much more like a System 2 process" (p. 268). Applying such claims to the ethical decision-making process, it seems reasonable to argue that the rationalist approach would consider moral reasoning as one of the processes of System 2, being the cognitive process system that any individual activates to evaluate carefully a situation, come up with a conscious and deliberate decision, and structure a course of action (Marquardt and Hoeger 2009; Provis 2015; Woiceshyn 2011). In contrast, intuitive judgment or moral intuition, being unconditional and spontaneously triggered, seems to be associated with the automatic reply of System 1 (see Fig. 2).

Despite purely intuitionist theories being quite categorical, it has been shown that, especially in uncertain, dynamic, and fast-changing circumstances, decision makers' System 1, which in moral terms is associated to the moral intuition process, becomes particularly relevant and effective in forming ethical judgments (Groves et al. 2008; Zhong 2011). However, this current work does not argue that such claims are absolutely correct; rather it seems important to acknowledge the role of intuition, as well as that of reasoning, in forming moral judgment, and blend these elements into an integrated framework, which stresses the significant function of both intuition and reasoning in ethical decision making (Dane and Sonenshein 2014; Sonenshein 2007; Weaver et al. 2014). The integrated model of ethical decision making we are going to present considers moral intuition as a pre-stage of the 'rational' ethical decision-making process, and in doing this we are taking into account both intuitionist and rationalist approaches in relation to the decision maker's ethical behavior.

\section{Moral Intuition in Ethical Decision Making}

Recent findings reveal that moral intuition, along with the emotional sphere of human cognition, plays a significant role in forming intuitive moral judgments (Cushman et al.

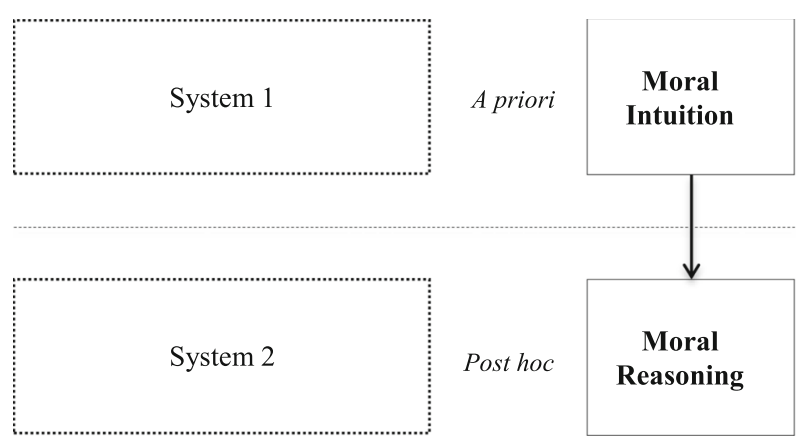

Adapted from Haidt (2001, p.815)

Fig. 2 An intuitionist framework of ethical decision making 
2006; Greene et al. 2001; Haidt 2001, 2003a). The attempt is to unpack moral intuition and deepen the notion of intuitive moral judgment as an integrated model (Fig. 3) that blends the intuitionist perspective with the traditional rationalist one.

\section{The 'Intuiting' Process}

Firstly, it is necessary to unpack the internal composition of moral intuition building on recent literature evidences. Dane and Pratt (2007) stressed a significant distinction between the process of intuiting and the outcome of moral intuition (p. 36), adding that the whole process is affectively charged (p. 40). Building on this, it is possible to unpack moral intuition into two processes, namely intuiting (Dane and Pratt 2007) and emotional processing (Greene et al. 2001), and the resulting outcome called affect-laden intuitions (Haidt 2007).

Decision makers' intuiting is a non-conscious cognitive process (Kihlstrom 1987), characterized by speed and fast information processing (Evans 2008; Kahneman 2003), able to seize external stimuli and to associate them with cognitive structures in a way that is interpretable by the decision maker's mind schemata (Epstein 1994). Hodgkinson et al. (2008) define intuiting as "an automatic self-process, initiated on the basis of explicitly or implicitly perceived cues that operates without effort, intention, conscious awareness or deliberative analytical judgments"
Fig. 3 The dual processing model of ethical decision making

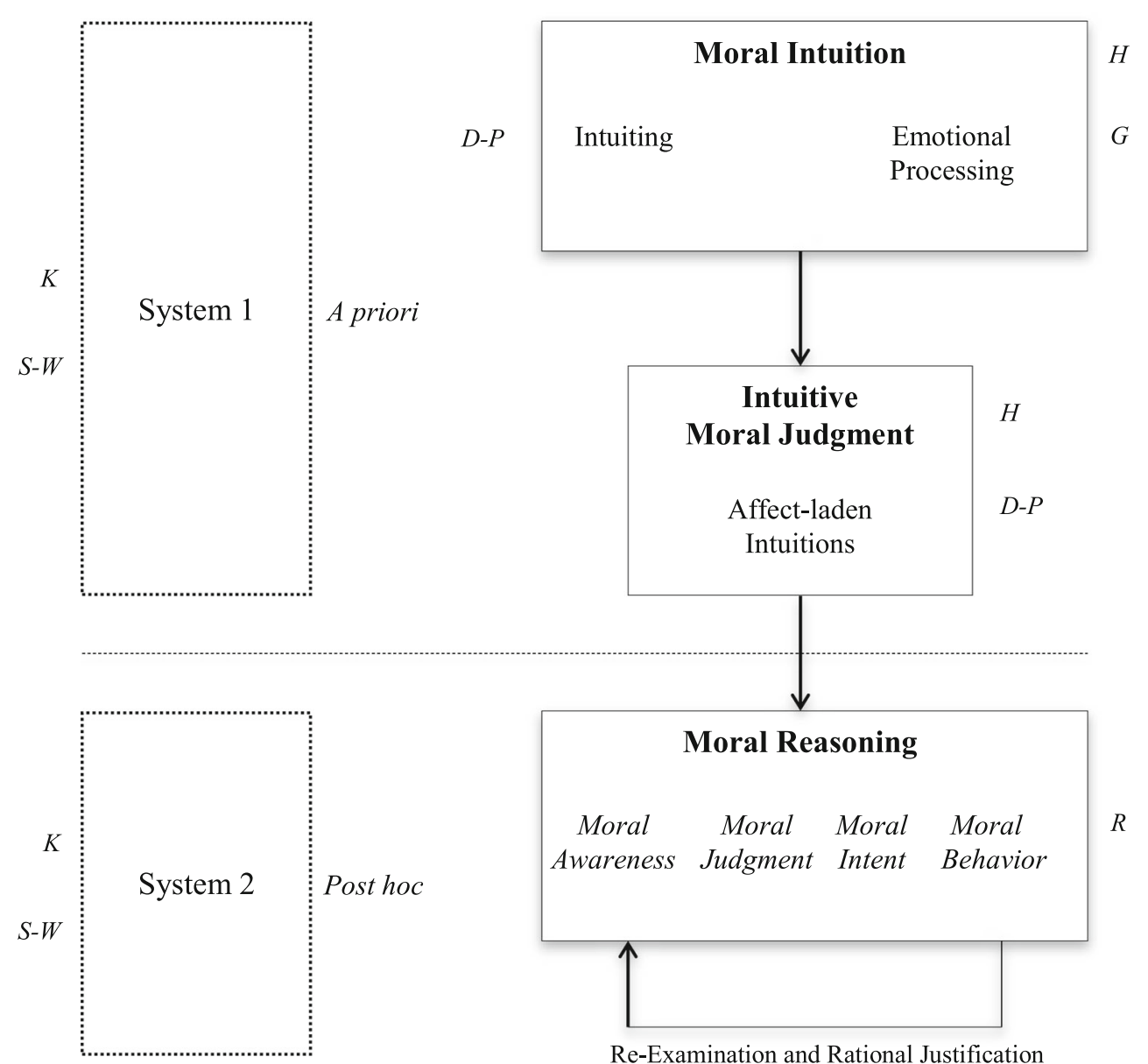

Key:

D-P = Dane and Pratt (2007)

$\mathrm{G} \quad=$ Greene et al. (2001)

$\mathrm{H} \quad=$ Haidt $(2001 ; 2007)$

$\mathrm{K}=$ Kahneman (2003)

$\mathrm{R}=$ Rest (1986)

S-W = Stanovich and West (2000) 
(p. 14). The authors agree with Dane and Pratt's differentiation (2007) between such a non-conscious process and its main outcome, namely intuition. Hence, intuiting may be interpreted as the first process of a decision maker's moral intuition, activated by the immediate, fast, effortful, and automatic System 1, through which decision makers seize apparently separated external stimuli that are unconsciously re-elaborated in a holistic way (Epstein 1994; Kahneman 2003; Kihlstrom 1987). It is also clear how the intuiting process works without any associations with System 2 processes, since it does not involve the decision maker's conscious awareness (Dane and Pratt 2007; Hodgkinson et al. 2008).

Intuiting acquires relevance in the decision-making process mostly in dynamic, unclear, and fast-changing contexts, which typically involve managers to 'cut through' details and information (Hodgkinson et al. 2008, p. 14), take a decision in ambiguous situations with poorly structured problems (Sinclair and Ashkanasy 2005), and rapidly exploit cognitive holistic associations in order to make a judgment (Dane and Pratt 2007).

\section{The Role of Emotion in Moral Intuition}

The framework proposed in this research sees emotional processing as the second process of moral intuition that comes after the intuiting one and represents an affective mediator inclining decision makers toward moral affectladen intuitions. Actually, affects and emotions represent a significant element of analysis in moral judgment and ethical decision-making research, both in the psychological field (Evans 2008; Fridja 1993; Greene et al. 2001; Haidt 2001, 2003b) and the managerial one (Agnihotri et al. 2012; Gaudine and Thorne 2001; Kim and Johnson 2013; Lurie 2004).

Traditionally, the debate concerning the role of emotions in human cognition has seen two different perspectives: firstly, the separation between emotion and reasoning (Zajonc 1984), labeling the former as 'emotional unconscious' (Greene et al. 2001; Kihlstrom et al. 2000). An opposite view instead sees possible the integration between emotion and reasoning, traditionally attributed to Lazarus (1984). The author interprets emotions as a result of reasoning and, therefore, as integral parts of it. Such a perspective may help in understanding the role of emotions as secondary and often detrimental to the decision-making process in general, and in the ethical debate consequentially (for an extensive review see Fridja 1993; Haidt 2003b; Kihlstrom et al. 2000). However, the modern psychological debate tends to mitigate such division, proposing models that follow the dual nature of the cognitive system. Particularly, Metcalfe and Mischel (1999) theorize a differentiation between the "hot emotional system," called the 'go' system, and the "cool cognitive system," defined as the 'know' one (p. 4). While the former shares the System 1 features, being reflexive, fast, and simple, the latter shares the System 2 characteristics, namely reflection, self-control, and slowness (Epstein 1994; Evans 2008). Hence, it is possible to recognize the existence of a 'hot' emotive system, which is "specialized for quick emotional processing," and of a 'cool' system "specialized for complex spatiotemporal and episodic representation and thought" (Haidt 2001, p. 823). Only basic emotions such as happiness, sadness, anger, surprise, and anxiety are parts of the 'hot' system; more complex emotions such as desire, disgust, jealousy, and empathy instead affect the higher-order reasoning, or in other words, the rational reasoning (Haidt 2003b; Metcalfe and Mischel 1999). Notwithstanding the influence that emotions have on ethical decision making, emotions will be interpreted only as an affective mediator of both the intuitive and rational moral judgment.

The proposed integrated model of ethical decision making fits well with such a perspective, proposing that the intuitive ability of the decision maker to perceive, reconstruct, and evaluate moral issues related to the ethical dilemma, largely depends on his/her emotional processing capacity that represents the affective component of intuition (Dane and Pratt 2007). In particular, the emotional processing is a significant mediator function played by affects and emotions channeling decision makers' intuiting toward affectively charged intuitions (Greene et al. 2001; Haidt 2001). This emotional processing encapsulates the experiential state of the decision maker during the actual circumstances, therefore playing a significant role in determining intuitive moral judgments (Greene et al. 2001; Marquardt and Hoeger 2009; Whitaker and Godwin 2013). For the purpose of a blended model of ethical decision making, it is important to acknowledge the existence of different types of emotions impacting on the ethical decision-making process, as will be presented clearly in the framework later, specifying that emotions affecting the intuitive and instinctual decision-making process, or moral intuition, belong to the 'hot' system. In contrast, emotions of the 'cool' system affect the rational and deliberative process, or moral reasoning. Thus, the emotional channeling in analysis here refers to the basic emotions related to the 'hot' system.

\section{The Intuitive Moral Judgment}

As outcomes of the whole moral intuition process, we have affect-laden intuitions, in a more psychological fashion, or intuitive moral judgments, in a more ethical fashion, which represent an a priori response that emerges in a fast and automatic way (Haidt 2007; Marquardt and Hoeger 2009) 
and result from an affectively charging process (Dane and Pratt 2007; Greene et al. 2001). While the two aforementioned processes of moral intuition are completely nonconscious, their outcome represented by intuitive moral judgments is accessible to the decision maker's conscious thinking (Dane and Pratt 2007; Hodgkinson et al. 2008). Such intuitive moral judgments are thus the base for an 'instinctual' response to a particular situation, usually unstructured, unclear, and dynamic. As illustrated in Fig. 3, intuitive moral judgments represent the outcome of moral intuition that will be rationalized by moral reasoning. Hence, if the moral issue becomes more structured and definite, the analytical and rational processes of System 2 seem more effective in producing an ethical judgment and a consequent ethical behavior (Hodgkinson et al. 2008).

Thus, moral intuition is unpacked in two processes and summarized in Table 1.

To summarize, moral intuition is the decision maker's ability to perceive a moral issue that, simultaneously and unconsciously, stimulates a reaction according to what are perceived as the most appropriate moral principles for the concrete situation (intuiting). This process also depends on emotions caused by the actual events and the experiential state of the individual (emotional processing). The resulting outcome is represented by intuitive moral judgments that a priori appear in the ethical decision-making process (affect-laden intuitions). In line with the intuitionist perspective, this research acknowledges that, in particular uncertain and dynamic contingencies, moral intuition and its outcomes may directly form a moral judgment, even without the rational deliberation of moral reasoning (Greene et al. 2001; Haidt 2001; Hodgkinson et al. 2008; Sonenshein 2007; Zhong 2011). However, at the same time, it is also true that deliberative and rational decisionmaking processes need to occur to strengthen or correct an intuition. Indeed, it is important to stress that decision makers are not "prisoners of their initial intuitions, unable to change their minds once they have taken a position" (Haidt 2003a, p. 197). Accordingly, the research proposes a blended and balanced model, taking into account the role of both moral intuition and moral reasoning on ethical decision making.

Finally, a recognition of the existence of moral intuition dispositional factors is necessary, especially at the individual level, along with the decision maker's experience, which may trigger moral intuition and the resultant intuitive moral judgments (Dane and Pratt 2007; Dane and Sonenshein 2014). The framework points to the inner dispositions that lead to moral intuition, similarly to the focus of a virtue ethics approach. However, a pure virtue ethics approach is not completely applicable, since a 'deliberate' practice, such as the case of virtues, seems not to be appropriate to describe moral intuition, which instead occurs effortlessly. For this reason, an aim of the paper is to

Table 1 Unpacking moral intuition's processes and outcome

\begin{tabular}{|c|c|c|}
\hline $\begin{array}{l}\text { Moral } \\
\text { intuition }\end{array}$ & Phases/outcome & References \\
\hline Intuiting & $\begin{array}{l}\text { A non-conscious cognitive process, characterized by fast, } \\
\text { automatic, and reflexive information processing activated by } \\
\text { System } 1 \text {. It allows decision makers to seize external stimuli } \\
\text { that are unconsciously re-elaborated in a holistic way, thus } \\
\text { implying rapid intuitive judgments } \\
\text { It represents the first phase of moral intuition and a cognitive } \\
\text { antecedent of the ethical decision-making process }\end{array}$ & $\begin{array}{l}\text { Dane and Pratt (2007), Epstein (1994), Hodgkinson et al. } \\
\text { (2008), Kahneman (2003), Kihlstrom (1987) }\end{array}$ \\
\hline $\begin{array}{l}\text { Emotional } \\
\text { processing }\end{array}$ & $\begin{array}{l}\text { The affective component of moral intuition that encapsulates } \\
\text { the experiential state of the decision maker, characterizing the } \\
\text { 'emotional unconscious' of human cognition. Within the } \\
\text { moral intuition process, it is labeled as the 'hot' emotive } \\
\text { system } \\
\text { It represents the second phase of moral intuition by channeling } \\
\text { the decision maker's intuiting toward affectively charged } \\
\text { intuitions }\end{array}$ & $\begin{array}{l}\text { Evans (2008), Gaudine and Thorne (2001), Greene et al. (2001), } \\
\text { Fridja (1993), Haidt (2001, 2003b), Kihlstrom et al. (2000), } \\
\text { Zajonc (1984) }\end{array}$ \\
\hline $\begin{array}{l}\text { Affect- } \\
\text { laden } \\
\text { intuitions }\end{array}$ & $\begin{array}{l}\text { The outcome of the two phases of moral intuition, which } \\
\text { automatically and instinctively produce intuitive moral } \\
\text { judgments } \\
\text { In our integrated framework, such intuitions a priori appear in } \\
\text { the ethical decision-making process and are afterward } \\
\text { rationalized by moral reasoning, thus producing post hoc } \\
\text { moral judgments }\end{array}$ & $\begin{array}{l}\text { Dane and Pratt (2007), Haidt (2007), Hodgkinson et al. (2008), } \\
\text { Greene et al. (2001), Marquardt and Hoeger (2009) }\end{array}$ \\
\hline
\end{tabular}


enrich the virtue ethics perspective thanks to a particular human innate habit traditionally associated with the scholastic moral philosophy, known as synderesis. This concept, as we will show in the next sections, perfectly suits the moral intuition paradigm and an integrated ethical decision-making model, such as the one we proposed.

\section{Synderesis in Scholastic Ethics and Moral Philosophy}

Scholasticism has represented one of the most important Christian medieval philosophies in Europe (for an extensive review see Dierksmeier 2013; Melé 2016). Recently, Melé (2016) defined the term scholastic as "a method and a system based on the rigorous conceptual analysis of different positions and a careful drawing of distinctions for a better understanding of questions under consideration" ( $p$. 294). Since scholasticism significantly contributed to the evolution of the Catholic school of thought, the present research drawing on such a discipline is completely in line with the modern Christian approach. Although two great scholastic periods can be traced, we draw our analysis from the First Scholasticism of the late Middle Ages (Dierksmeier 2013; Melé 2016), particularly from the main Franciscan and Dominican intellectuals who mostly contributed to the development of the notion of synderesis, which is the object of the analysis of the present paper.

The Christian concept of synderesis has ancient origins rooted in scholastic theory that defines it as a practical natural habit (Das Neves and Melé 2013) and a cognitive innate disposition (Greene 1991; Kärkkäinen 2012). In this work, a comprehensive perspective of this concept is included; it follows the long-lasting tradition of the scholastic school (Greene 1991, 1997; Lottin 1942; Ojakangas 2013; Potts 1980), integrating and enlarging the original thoughts of Aquinas (Summa Theologica, hereafter S. Th., ed. orig. $1265-1274 ; 1947)$. This attempt is made in order to enrich the modern debate on ethical decision making by integrating the role of moral intuition and moral reasoning in the human cognitive process. Indeed, the research follows a broader definition and notion of synderesis, seen as a natural, innate and affective trait, building on the scholastic works of St. Bonaventure (Itinerarium mentis in Deum, ed. orig. 1259; 1956) and Jean Gerson (De Theologia Mystica, ed. orig. 1420; 1958) that seem to be more in line with the recent psychological research on moral judgment. This approach is preferred, rather than a strict adherence to the 'cognitivist theory' of Aquinas (Gorevan 2000, p. 141), in order to still use and enlarge the Thomistic tradition, which is considered highly valuable and capable to interpret even the most recent evidences of the psychological evolution. Such a theoretical building allows this work to propose an integrated model that is in line with modern psychological theories of moral behavior, particularly the socio-intuitionist model (Haidt 2001, 2007), which stresses the effective role of moral intuition in the ethical decision-making process.

As shown later, in the specific analysis of the concept of synderesis, the analysis used a time-spanning lode of scholastic studies in order to define this concept, including facets of Aquinas' original thought. Despite that, a necessary premise seems to be required. The perspective adopted in this study assumes synderesis to be an instinctus naturae-a divine natural instinct present in every human being-capable of providing moral inclination, thanks to the natural law implanted by God in men's souls (for a commentary see Greene 1997, p. 180; Ojakangas 2013, p. 53). This perspective, specifically derived from the scholastic theory of the thirteenth century, provides elements in line with Aquinas' traditional definition and concept of synderesis $(S$. Th., $\mathrm{I}^{\mathrm{a}}$, q.79, a.12; $\mathrm{I}^{\mathrm{a}}-\mathrm{II}^{\mathrm{ae}}$, q.94, a.2); however, this research also significantly departs from it. More precisely, Aquinas-the most influential Dominican intellectual of the First Scholasticism (Melé 2016)—describes synderesis as "the law of our intellect insofar as it is the habit that contains the precepts of natural law, that is, the first principles of human actions" (S. Th., I'-II ${ }^{\text {ae }}$, q.94, a.2). Thus, as in the approach adopted in this research, the natural essence of synderesis is extensively present in Aquinas' thought (Quaestiones Disputatae de Veritate, hereafter De Veritate, ed. orig. 1256-1259; 1972, q.16, a.1, arg.5). The universal principles of law are attributed to synderesis, which is consequently interpreted as the natural ability of humans to judge (Celano 2013; Lottin 1942). Specifically, Lottin (1942) recognizes natural law as constituted by the universal principles of morality and synderesis as the human innate disposition able to reveal them (p. 569). In the Thomistic perspective, synderesis is interpreted in a pure, cognitive way by defining it as a natural habit that represents an integral element of the human reasoning process $\left(S\right.$. Th., I ${ }^{\mathrm{a}}$, q.79, a.12), which allows the pursuit of moral principles and influences individuals' ability in discerning moral decisions from immoral ones (De Veritate, q.16, a.1, a.2; q. 17, a.1, a.2). Aquinas in associating the innate habit of synderesis with the principles of natural law was influenced by Philip the Chancellor's Summa de Bono (1985, pp. 1225-1228), one of the first theological treatises on morality, where synderesis is interpreted as a component of the highest part of the human soul that "directs human judgments toward goodness and away from evil" (Celano 2013, p. 12; see also Lottin 1942). Particularly, Philip distinguishes synderesis, interpreted as "voluntas naturalis," from human "liberum arbitrium" (free choice), in that the former is naturally directed toward good while the latter may be attracted both by moral and immoral choices (Summa de Bono, I, 162-167). 
Whereas Aquinas defines synderesis as an intellectual disposition of human beings, different interpretations of the concept are especially attributed to the works of St. Bonaventure (1956) and Gerson (1958). St. Bonaventure, who is the Franciscan intellectual leader of the First Scholasticism (Melé 2016), associates the term synderesis with the notion of instinctus naturae (natural instinct), adding that synderesis operates at the affective and emotional level in order to incline man toward morality without deliberative efforts (Greene 1991; Lottin 1942; Ojakangas 2013). Hence, St. Bonaventure (In Quartum Librum Sententiarum, ed orig. 1259; 1889) defines synderesis as an affective habit of the natural will, reinterpreting Lombard's seminal definition (Liber Primus Sententiarum, ed. orig. 1152; 2007) of the term, which refers to man's will being naturally inclined toward morality (Potts 1980). Building on Bonaventure's definition, Greene (1997) states, "So synderesis has now become the term for that involuntary orientation and movement of the natural will in the affective part of man's soul" (p. 187; see also Ojakangas 2013 and Potts 1980). Accordingly, Gerson (1958) interprets synderesis as an instinct that comes directly from God and inclines humans toward morality, specifically defining synderesis as a human "ineradicable instinct (instinctus indelebilis)" (Ojakangas 2013, p. 54). Gerson differentiates between cognitive and affective human powers and collocates synderesis at the top of affective powers, defining it as an instinctus naturalis in boni (natural instinct for good) (Greene 1997, p. 190); however, such an interpretation of synderesis is largely accepted - even in previous studies. For example, in support of this claim is the position of the scholastic theologian Thomas Gallus (Commentary on Isaiah, ca. 1218; for a commentary see Javelet 1961) who clearly separates human intellectus (intellect) from affectus (affection) and, in doing so, associates synderesis with the notion of principalis affectio (main affection) (Javelet 1961, p. 289). Hence, the interpretation adopted here about the nature of synderesis is in accordance with this latter perspective; synderesis is considered to be an 'instinct' rather than a deliberative process as with the original Aquinas thought.

Building on scholastic theories that stress the affective, natural and innate features of synderesis, the next sections highlight how such a concept of the Christian tradition can be perfectly blended in an ethical decision-making model by considering both moral intuition and moral reasoning.

\section{Synderesis as Innate Inclination Toward Moral Intuition}

Synderesis has an important role in Christian tradition, as its origin demonstrates. The first appearance of the term refers to Saint Jerome who in the year 415 cited this word in his Commentary on Ezekiel's vision of four creatures with different faces, namely a human, a lion, an ox, and an eagle, supporting the divine throne (Lombard 2007; for a review see Langston 1993, 2011). The Saint associates synderesis with the eagle representing the spark of human reason and revealing "the candle of the Lord" that allows moral discernment (Greene 1991, p. 196; see also Greene 1997; Kärkkäinen 2012). Actually, among medieval scholastic theologians, this interpretation is recurrent and synderesis is the scintilla rationis (spark of reason) related to a natural inclination of human beings toward intuitively discerning the correct act (Greene 1991, 1997; Lottin 1942; Potts 1980). This is possible thanks to the principles of the natural law imprinted, for the tradition, in the soul of each individual (Bonaventure 1956; Lombard 2007). According to these early scholastic constructs, the concept of synderesis highlights its main feature, i.e., innate nature (Greene 1991, 1997).

This element is perfectly in line with the characteristics previously attributed to System 1 and so to moral intuition. Thus, synderesis seems reasonably the 'correct' natural habit used during the process of moral intuition; in other words, synderesis is the correct habit that regulates intuition due to its innate nature and it is present in every individual.

\section{Synderesis as the Catalyst of Intuitive Moral Judgments}

In the late Middle Ages and during the Renaissance, the relationship between the innate natural habit of synderesis and human moral behavior received widespread attention (Greene 1991, 1997; Kärkkäinen 2012). For Gerson (1958), synderesis is a guiding ability of human cognition toward moral principles (Greene 1991). Similarly, the Thomistic philosopher Peyligk, in Philosophie naturalis compendium (1499), interprets synderesis as an affective disposition that follows universal moral principles, thus inclining human behavior toward good (Kärkkäinen 2012). This role of synderesis, which in such a perspective is assimilated to human natural law, inclines human behavior toward moral evaluation and moral decision (Greene 1997). Also Martin Luther (Dictata Super Psalterium ed. orig. 1515; 1964), with a completely different ontology, sees synderesis as a human cognitive ability to avoid immoral decisions, thus aiming at the most morally correct behavior.

The common ground of all these interpretations is that synderesis inclines decision makers' cognition toward moral judgment without what today would be called a proper process of rational deliberation; it allows "the immediate grasp of concrete reality" without conscious reasoning (Liebert 2008, p. 74). Hence, this Christian 
concept seems to be in line with the recent social intuitionist model that indeed attributes to moral intuition an a priori cognitive function influencing post hoc moral reasoning. Such an aspect of synderesis is extremely relevant to the present conceptualization; in particular situations, i.e., dynamic and uncertain conditions, thanks to synderesis the intuitive moral judgment made by moral intuitioneven without a deliberate process-can result as being rightful. This concept can be further discussed; considering synderesis as capable of conferring rightful connotations to moral intuitive judgments would imply that even without a deliberate effort these judgments are 'embryonically' or 'primordially' inclined toward goodness. Thus, synderesis renders rightful the intuitive moral judgment even without a deliberative cognitive effort.

\section{Synderesis as an Antecedent of the Ethical Decision-Making Process}

Commonly, synderesis is seen as a trustworthy part of the soul, a kind of primal conscience able to predispose to goodness (for a review of this interpretation see Benedict XVI, On Conscience, 2007). Similarly, in a more managerial fashion, Das Neves and Melé (2013, pp. 773-776) argue that synderesis refers to the innate natural cognitive habit that allows decision makers to seek moral behavior, make moral judgments, and reject evil temptations.

Synderesis, as already shown in medieval interpretations, is an innate ability to readily discern the natural law principles. However, the natural law by its nature is the primordial imprinting given by God to the human soul to be prone instinctively (innately) to goodness (Das Neves and Melé 2013). Thus, the natural law is a universal truth that is utterly trustworthy, and its moral principles indicated by synderesis are infallible (De Veritate, q.16, a.2; q.17, a.2). However, this broad interpretation requires a more specific discussion about synderesis to avoid confusion and overlap with other concepts still related to ethical decision making. The first differentiation is with conscience, "synderesis grasps the basic moral principles which are the first premises of practical reasoning, while conscientia (conscience) is the conclusion, the act of judging that one ought to perform a particular action" (Korsgaard 2013, p. 110). In addition, Dierksmeier and Celano (2012) also argue that synderesis represents a perpetual human moral principle constantly inclining toward rectitude, a concept also found in the thoughts of Aquinas (Scriptum super Libros Sententiarum, ed. orig. 1254-1256; 2000, II, d.24, q.3, a.3). This aspect differentiates synderesis from individual conscience that can be obstructed by faulty moral reasoning (Korsgaard 2013). On the same level, Verplaetse (2009) also stresses the difference between synderesis, considered as the infallible divine precept present in every individual, and conscience, interpreted as the application of that infallible set of principles that may result in immoral behavior caused by misleading reasoning. Whether or not these approaches are completely to be espoused, the common and relevant aspect for this research is that synderesis is the habit that precedes the cognitive stage of moral reasoning. Yet, synderesis seems to suit a 'balanced' framework that integrates both the rationalist and intuitionalist approach. As premised in the previous paragraph, synderesis confers rightful contents to intuitive moral judgments; such 'judgments' are also used in the formal or rational processes of moral reasoning. Hence, it is possible to summarize that synderesis is an antecedent of the ethical decision-making process, giving the rightful base from which to develop a complete moral decision.

\section{Synderesis as an Innate and Acquired Habit: The Dual Nature of Synderesis}

The previous sections showed how (1) synderesis as an innate habit is the correct basis that can be applied to moral intuition; (2) synderesis confers rightful connotations to intuitive moral judgments without a deliberative effort; and (3) synderesis is considered to be an antecedent of moral reasoning. However, synderesis does not only 'offer bases' for moral reasoning, it concretely contributes to reasoning's perfection.

In order to apply such a scholastic notion to an integrated framework that attempts to combine the intuitionist and rationalist perspectives, the research specifically refers to the Dominican theologian John Poinsot (Tractatus de Signis, ed. orig. 1632; 1985). Poinsot, in his discussion about the "natural' and 'acquired' aspects of synderesis habitus (habits), describes them as "partim acquisiti, partim naturales" (partially acquired, partially natural) (Forlivesi 1993, p. 398). Despite the fact that such a differentiation does not emerge in the original thoughts of Aquinas, the Saint already theorized some kind of seminal elaboration on this topic by separating the 'affective knowledge,' called per quandam connaturalitatem (on account of connaturality), from the knowledge called per modum cognitionis (on account of reason) (S. Th., $\mathrm{II}^{\mathrm{a}}-\mathrm{II}^{\mathrm{ae}}$, q.45, a.2). According to Smith (1998), "Aquinas argues regarding the first principles of prudential practice that they are known to us 'by nature', that they are 'connatural to us' (connaturalia homini), and that they can be known by 'natural temperament' (naturali dispositione)" (p. 38). Building on this differentiation, Poinsot (1985) interprets synderesis, firstly, as a natural human habit naturally inclined toward deep-rooted moral principles of the natural law that intuitively disposes toward correct and moral 
judgment, what can be called innate synderesis. Secondly, synderesis is also an acquired faculty that, according to environmental and experiential factors, is assimilated by the individual's reasoning. This acquired faculty 'pushes' the rational reasoning toward correct behaviors (Forlivesi 1993). This second dimension, which we call acquired synderesis, is not fully natural, despite the principles to which it refers being universally true (natural law). In this regard, acquired synderesis requires an effortful and continuous engagement toward finding moral principles, and needs to be practiced at any occurrence, similarly to the traditional definition of virtue (Aristotle, Nicomachean Ethics, hereafter NE, VI, 5, 1138b24ff; 1998).

Innate synderesis in the model presented, which wants to include the intuitionist approach in ethical decision making, plays a major role and it has been thoroughly examined in the previous discussion. However, we cannot deny the fact that synderesis, the acquired one this time, may also influence moral reasoning directly, inclining it toward goodness. In a concise way, firstly, the natural habit of synderesis or innate synderesis is a pre-rational cognitive disposition that helps intuition by taking into account universal moral principles. Secondly, the acquired habit of synderesis or acquired synderesis inclines the rational cognitive process toward good, so that the rational deliberation does not draw away from universal moral principles.

\section{The Role of Synderesis in the Dual Processing Model of Ethical Decision Making}

After we built the set of considerations about synderesis by drawing upon scholastic moral philosophy (Bonaventure 1956; Gerson 1958; Poinsot 1985), blending them with recent psychological approaches (Haidt 2001, 2007; Haidt and Bjorklund 2008), we propose an integrated model of ethical decision making highlighting the role of synderesis (Fig. 4). We will illustrate how, firstly, synderesis in its 'innate' part may represent the initial input in forming a spontaneous and instinctive intuitive moral judgment and, secondly, synderesis in its 'acquired' part is a significant influencing element for the moral reasoning phase. In the next sections, we will give a full account of the links and influences that synderesis has on the whole ethical decision-making process, both on moral intuition and its elements, i.e., intuiting, emotional processing and affect-laden intuitions, and on moral reasoning.

\section{The Role of Synderesis in Moral Intuition}

The fundamental function of innate synderesis, interpreted as an innate human habit, is to facilitate and prompt ethical decision making in order to let the decision maker immediately discern ethical from unethical behaviors. Synderesis reflects well the essence of Christian ethics that prescribes the moral standards decision makers have to follow in order to discern between 'right' and 'wrong' (Kim et al. 2009, p. 119). As a result, we may argue that synderesis supports ethical decision making in a business context, fostering a moral disposition toward good behaviors.

As shown in Fig. 4, the innate synderesis triggers moral intuition. Specifically, the role of synderesis refers to the ability to balance both intuiting and emotional processing, i.e., the two processes of moral intuition. Specifically, innate synderesis shapes the decision maker's rapid and unconscious intuiting that represents the first process of moral intuition (Dane and Pratt 2007; Haidt 2001; Hodgkinson et al. 2008). As we said, the intuiting process of decision makers is a fast and reflexive process that automatically appears in consciousness (Dane and Pratt 2007). Since synderesis seems to trigger practical reason (Das Neves and Melé 2013), at an unconscious level it enriches the decision maker's intuitive system. The concrete situation in which a moral issue takes place impacts on the experiential system of the decision maker (Dane and Sonenshein 2014; Marquardt and Hoeger 2009; Whitaker and Godwin 2013) and, regarding the intuiting process, we may argue that innate synderesis facilitates a continuous, increasing reception of external stimuli present in a moral issue. Although an unconditional process, intuiting imprints the experiential system of the decision maker who will feel an easiness/uneasiness in performing such an act. Thus, innate synderesis due to its intrinsic nature and being the 'spark of conscience' (Celano 2013; Greene 1991; Langston 1993) can be a reasonable element to strengthen the experience toward critically 'assessing' the situation and increasing the reception of external stimuli within the situation. Hence, we propose that:

Proposition 1: Innate synderesis impacts on the decision maker's unconscious cognitive process of intuiting by promptly predisposing the intuitive reception of external stimuli toward morality.

Once the intuiting process is accomplished, the next process refers to the emotional processing of the decision maker's moral intuition (Greene et al. 2001). The innate synderesis is crucial in emotionally channeling moral intuition. Depending on the emotional state of the decision maker, opposite feelings such as happiness and anger, or any other emotion belonging to the 'hot' system (Metcalfe and Mischel 1999), may alter the reception of signals and limit the spectrum of information available in that particular moment (Haidt 2001, 2003b). As argued by Whitaker and Godwin (2013), "fearful individuals favor deliberation and safety, whereas anger leads to less analysis and more 


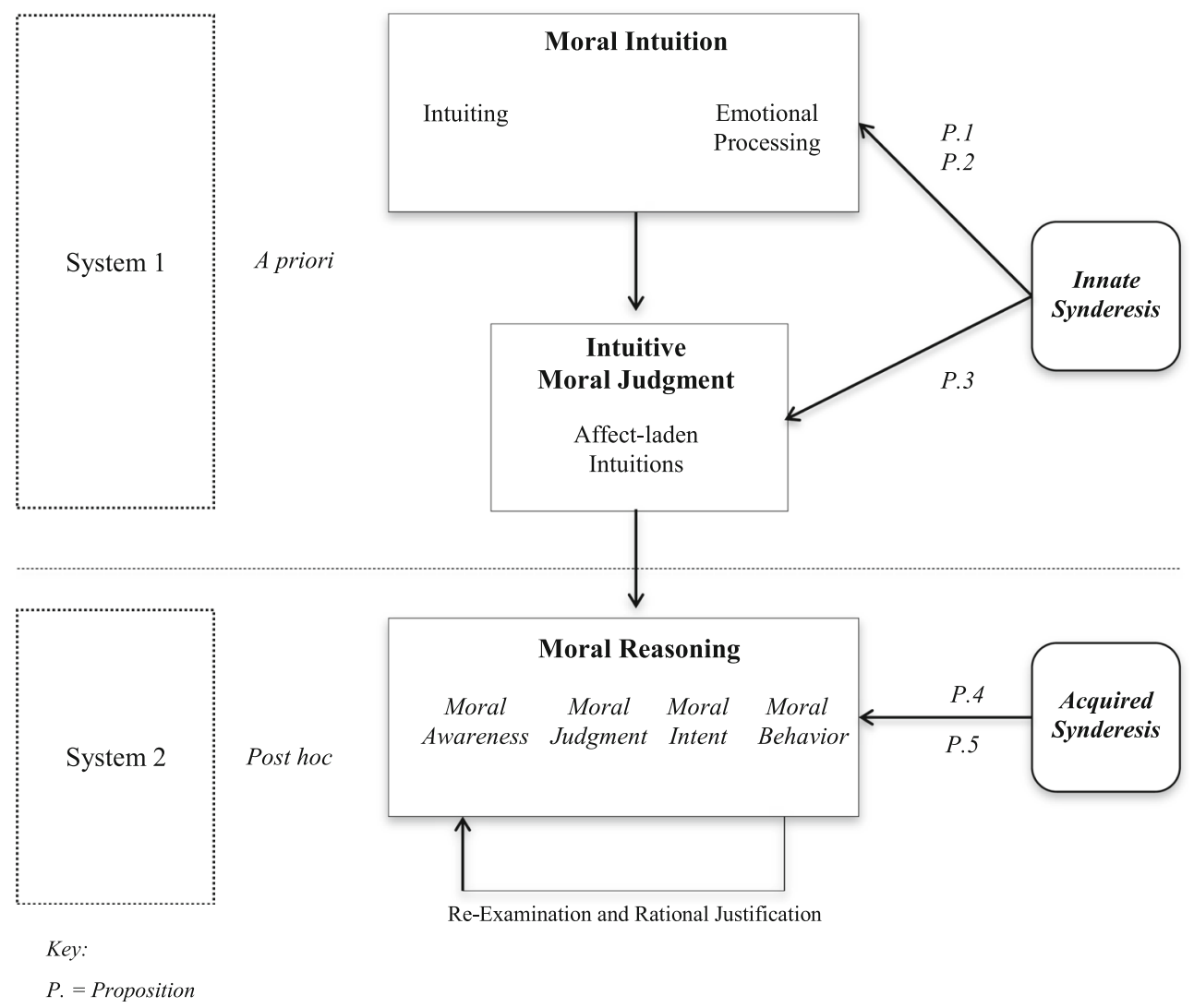

Fig. 4 The role of synderesis in the dual processing model of ethical decision making

risk-taking" (p. 63). Thus, decision makers' feelings notably affect the evaluative process (Marquardt and Hoeger 2009). Instead, innate synderesis firmly leads the decision maker's intuiting toward universal truth and moral principles, thereby regulating possible excessive emotional reactions. Psychological research would support such a claim, referring to the fact that emotions and intuition are linked one to another thanks to the experiential system (Dane and Sonenshein 2014; Epstein 1994). Hence, in such a cognitive area, emotionally significant experiences influence the decision maker's moral intuition, reflecting prior social events and past learning that morally affected the individual information processing systems.

So, innate synderesis, in framing the experience of the intuiting toward the goodness thanks to a balanced emotional channeling process, attenuates dystonic learning loops. We propose that:

Proposition 2: Innate synderesis attenuates the decision maker's altered emotive condition, due to the most basic emotions associated with the intuitive cognitive system, by regulating possible variations of his/her experiential state in order to channel the emotional processing toward pure moral principles.

\section{The Role of Synderesis in Intuitive Moral Judgments}

The main results of moral intuition are intuitive moral judgments (Dane and Pratt 2007; Haidt 2001), interpreted as rapid responses to the ethical dilemma a decision maker has to tackle. These judgments are affect-laden intuitions (Haidt 2007) as a result of emotions, feelings, past and current experience, and environmental factors that meaningfully impact on the decision maker's cognitive moral development (Groves et al. 2008; Kohlberg 1969; Marquardt and Hoeger 2009). Innate synderesis firstly allows the decision maker to channel external stimuli and his/her affective emotions toward an ethical decision; secondly, innate synderesis allows decision makers to respond according to appropriate moral principles for a particular situation, thus disentangling moral dilemmas and forming the resulting affect-laden intuitions. We acknowledge the fact that this process is mostly unconscious (Dane and Pratt 2007; Hodgkinson et al. 2008; Kahneman 2003), so cannot be handled by the decision maker personally but only through an experiential learning circle that, only at a later stage, becomes 'familiar' to the cognitive structure (Dane and Sonenshein 2014; Epstein 1994). 
We argue that the main result of intuitive moral judgment is the decision maker's 'moral labeling' of the particular situation, exactly as traditional frameworks stress for Rest's moral judgment (Morales-Sánchez and CabelloMedina 2013, p. 718). Also, innate synderesis, as the antecedent of moral reasoning, regulates the right 'use' of intuitive moral judgments. It fosters the balancing of the whole ethical decision-making process, avoiding an excessive reliance only on intuitive moral judgments that "can lead to injudicious ethical decision making without careful consideration of rational information sources" (Groves et al. 2008, p. 307).

Hence, the following proposition can be made:

Proposition 3: Innate synderesis inclines the decision maker's intuitive moral judgments toward morality by attenuating possible distortions caused by an excessive reliance on intuitional processes.

Synderesis fits perfectly into a dual model where both of the processes, i.e., moral intuition and reasoning, are included. In other words, synderesis also fosters decision makers' moral reasoning inputs. However, we want to stress that in uncertain, dynamic, and equivocal contexts that characterize the modern business scenario (Groves et al. 2008; Pellegrini and Ciappei 2015), the role of automatic and rapid moral evaluations represents a significant element (Dane and Pratt 2007; Weaver et al. 2014). For this reason, it is important to refer to the connotation of morality that already intuitive moral judgments have, since this may be the only base used in such circumstances.

\section{The Role of Synderesis in Moral Reasoning}

Building on the social intuitionist approach, in our integrated model the cognitive functioning of moral reasoning is positioned after moral intuition's main outcome, namely intuitive moral judgment (Haidt 2001, 2007), as shown in Fig. 3. Hence, moral reasoning is interpreted as a post hoc process that works with a conscious, deliberative, and intentional effort (Provis 2015; Weaver et al. 2014; Zhong 2011). However, it is important to stress that our model does not want to convey the idea that moral reasoning is only an instrument to 'rationalize' intuition, or that it has a subsidiary role. We are instead supporting the fact that, as antecedents to moral reasoning, there exists some kind of natural intuition of the ethical dilemmas, but at the same time we fully acknowledge the substantial role of moral reasoning in better elaborating and processing an intuitive moral judgment, or even rectifying it.

The aim of moral reasoning is to follow predetermined moral principles so as to address the moral issue of the actual situation faced by the decision maker (Buchholz and
Rosenthal 2005). As a result, the main function of moral reasoning is firstly to evaluate the dilemma analytically and rationally, and later provide moral justification for the chosen behavior. At this stage, the decision maker's $a c$ quired synderesis, interpreted as a human cognitive faculty resulting from past and current experiences and environmental influences, allows the avoidance of excessively rational deliberations that could lead to insensitive analysis and erroneous calculations at the expense of the ethical decision-making process (Groves et al. 2008). Indeed, $a c$ quired synderesis impacts on the argumentative rational justification of the decision maker's moral reasoning, weakening the insensitive deviations (Buchholz and Rosenthal 2005). The function of acquired synderesis is to incline moral reasoning and ethical behaviors toward goodness, if distortions of some post hoc reflections have occurred for any reason, pointing back to the process of the natural principles that synderesis is innately predisposed to find. In this way, re-evaluations and examinations of moral reasoning are morally balanced by the decision maker's acquired synderesis. As a result, we argue that:

Proposition 4: Acquired synderesis controls possible distortive rationalization of the ethical decision making thanks to elevating the individual justification from an argumentative level to a genuinely moral one, assuring the acknowledgment of universal moral principles.

Finally, in such a deliberative phase, it is important to recognize another role of acquired synderesis which consists of controlling the emotions influencing the rational sphere of human cognition, i.e., what we previously refer to as belonging to the 'cool' system (Evans 2008; Haidt 2001; Metcalfe and Mischel 1999). Particularly, such a system is affected by emotions that literature has defined as 'moral,' which play a significant role in forming moral judgment and ethical behavior (Haidt 2003b). Haidt (2003b) labels as 'moral' those "emotions that are linked to the interests or welfare either of society as a whole or at least of persons other than the judge or agent" (p. 853).

The 'hot-cool' theory of emotion (Metcalfe and Mischel 1999) is in line with the original conceptualization of Thomas Aquinas on the topic (S. Th., $\mathrm{I}^{\mathrm{a}}-\mathrm{II}^{\mathrm{ae}}$, q. 22, a. 1; see also King 1999). Particularly, Aquinas recognizes the existence of sensitive and intellective parts of the soul, both of which have cognitive and appetitive principles $(S$. Th., $\mathrm{I}^{\mathrm{a}}-\mathrm{II}^{\mathrm{ae}}$, q. 26, a. 1), and thus also two different types of human will that oversee the appetites. The voluntas ut natura (natural will) denotes a spontaneous will of the decision maker toward bonum (good), while the voluntas ut ratio (rational will) refers to a deliberative decision-making process toward verum (truth) (S. Th., III ${ }^{\mathrm{a}}$, q.18, a.4). Actually, it is possible to say that the natural will 
corresponds to the process of handling 'sensitive emotions,' denoting a spontaneous and natural inclination of human will toward morality, well exemplified by the love of God that may produce a natural inclination toward moral knowledge (S.Th., I ${ }^{\mathrm{a}}$, q.1, a.6). In contrast, the rational will deal with 'rational emotions' influencing the cognitive inclination of human will toward the truth (Gorevan 2000; King 1999). The present interpretation therefore sees sensitive emotions as basic emotions associated with the 'hot' system that takes place in System 1, while rational emotions as higher-order reasoning emotions are associated with the 'cool' system that takes place in System 2 (Evans 2008; Metcalfe and Mischel 1999). We also know that emotions may have a negative effect on moral reasoning, in line with Aquinas' interpretation of passions as 'obstacles' that 'pervert' human reason (S. Th., $\mathrm{I}^{\mathrm{a}}-\mathrm{II}^{\mathrm{ae}}$, q. 94 , a. 4). The significant role of acquired synderesis refers to preventing the possible 'clouding' of a decision maker's ethical judgment being the scintilla rationis-'spark' of conscience (Lombard 2007) — that gives the rightful base for a deliberative cognitive effort directed toward moral discernment (Bonaventure 1956; Gerson 1958).

Also in the literature about ethical decision making, increasing attention has been dedicated to the impact of emotions on moral reasoning (Agnihotri et al. 2012; Gaudine and Thorne 2001; Lurie 2004). Gaudine and Thorne (2001), for example, theorize a 'cognitive-affective' model recognizing positive impacts on all the four stages, i.e., moral awareness, moral judgment, moral intent, and moral behavior. Other researches similarly reveal how instead some emotions seem to be more impactful on some moral stages than on others (Agnihotri et al. 2012; Lurie 2004). According to Melé (2005), positive emotions such as compassion, solidarity, and sympathy, but also negative emotions such as greed and self-sufficiency, significantly impact on the decision maker's awareness of a moral issue. Such emotions working at the rational level are labeled 'moral sentiments' (Melé 2005, p. 104), which differ from the sensitive basic emotions working in the intuitive 'hot' system described above.

This allows us to extend the original Thomistic thought toward an integrated ethical decision-making framework, which also considers both kinds of emotion and their roles in respect to moral intuition and moral reasoning. To summarize:

Proposition 5: Acquired synderesis prevents emotions, i.e. those that are more sophisticated and associated with the deliberative cognitive system, from clouding the rational evaluation of moral dilemmas by redirecting the rational process to the ultimate state of truth.

\section{The Employability of the Concept of Synderesis in a Dual Processing Model}

This distinctive nature of synderesis makes it a unique approach for analyzing the ethical decision-making process through a dual perspective, i.e., integrating intuitionist and rationalist perspectives. We offer a brief explanation of such a claim, showing the drawbacks of other traditional, ethical paradigms used in the ethical decision-making literature, i.e., utilitarianism, universalism, and (purely) virtue ethics (Koehn 1995). According to the utilitarian rationale, decision makers evaluate and choose the alternatives depending on the expected effects, thus enhancing their satisfaction/utility (Kim et al. 2009). Despite the different sophistications of the utilitarian approach, a common element of all these theories is that the agent is rational and able to evaluate the situation and its outcome. Definitely, such requisites are not met by talking about intuition, especially the ability to forecast and choose the preferable outcomes. Conversely, universalism imposes that every act is performed according to general and transcendental moral principles (Kant, Foundations of the metaphysics of morals, ed. orig. 1785; 1959). So, from this perspective, the traditional way to exert a decision-making process is through applying universal concepts to the particularities of reality, i.e., the determinant judgment (Kant, Critique of Judgment, ed. orig. 1790; 1914; 5: pp. 386-389). However, another kind of judgment is also present, i.e., reflective judgment, where peculiarities of reality are connected with universal concepts given by pure reason. This form of judgment may suit the intuition process more; however, as Kant (1914) himself declares, a reflective judgment is carried out through confrontation and dialectics and again this connotation does not completely suit an instinctive process.

Finally, virtue ethics refer to specific human qualities, or virtues that are dispositions acquired, exercised, and instructed by moral actions (Crossan et al. 2013; Melé 2005). Our approach actually draws really close to the virtue ethics paradigm; however, a strict application of that paradigm would imply asserting that intuition needs to be exerted in an effortful way. While we may agree that even this unconscious process can be sharpened to some extent, nevertheless it will never be completely under control-as a proper virtue or moral habit would require. However, our elaboration of synderesis better suits an integrated model. Synderesis is both a typically innate and natural human sense, such as moral intuition (Haidt 2001), and partially acquired and partially natural (Forlivesi 1993; Poinsot 1985), which satisfies the traditional criteria of a 'proper' virtue ethics approach, and its virtuous action influences the moral reasoning process more. 
Another consideration to be made is that synderesis, despite having two constituent parts, is not a virtue per se. Actually, in line with the Thomistic tradition, we acknowledge the fact that in order to be virtuous, the decision-making process needs moral reasoning. In fact, innate synderesis regulates the intuitive process and in this way offers an embryonic intuitive moral judgment inclined toward goodness. We are claiming that this basic moral, natural and innate intuition of morality is 'intrinsically' connatural in all human beings (Dierksmeier and Celano 2012), and also in accordance with the scholastic thoughts of Bonaventure (1956) and Gerson (1958). However, in order to act completely virtuously, this natural inclination is not enough; it is necessary to have the support of all the other cardinal virtues (S. Th., $\mathrm{I}^{\mathrm{a}}-\mathrm{II}^{\mathrm{ae}}$, q.61, a.1). For example, without practical reason such good initial intuition can be translated into careless behaviors, or without fortitude the planned and intended behaviors can be weakened by the harshness of contingencies. Thus, for all these reasons, synderesis is able to give moral content to intuition but this is only what we can call a 'moral premise' that does not necessarily lead to virtuous behaviors. However, it is also true that, without such a universal innate ability oriented toward goodness, the possibility of being virtuous would be much more impaired. Yet, neglecting the naturally and innate inclination toward the morality of human beings would imply a dangerous assumption about human nature seen as innately sterile, if not worse, i.e., wicked, opening up for a dangerously moral relativism or situationalism (Lewis 1989).

Probably, a much better assumption would be to consider synderesis as the habit that to some extent contributes to what the Ancient Greeks would refer to as enkrateia, which means 'continence or self-mastery' (NE, VII, 8, 1151a27-28; see also Arjoon 2008). Such a state is related to a situation in which the decision maker, despite appetites and emotions, is able to act according reason, thus reaching a moral behavior even without the intervention of a virtuous process (Arjoon 2008, p. 228). We admit that enkratic people in this perspective are seen as rationalist agents but, as we stressed many times within this work, our principal aim is to give theoretical foundations to the last evolutions of psychology by highlighting the significant role of moral intuition for an integrated ethical decision-making process. Thus, synderesis leads to self-mastery (enkrateia) as far as it regulates emotions and instincts, particularly the most irrational and 'eruptive' of the 'hot' system during the intuitive phase (innate synderesis). At the same time, during the 'rational' process, it preserves the decision maker's cognitive process from distortions that would deviate reasoning from moral judgment and behavior (acquired synderesis).

Specifically in relation to the virtue of practical reasoning, the 'acquired' feature of synderesis (Poinsot 1985) — which constantly reminds of innate moral contents during moral reasoning-seems able to facilitate the application of such a virtue to a potential or virtual status. This is a premise for an executive habitus that, finally, implies a virtuous behavior. Decision makers unconsciously elaborate intuitive moral judgment, as we said through innate synderesis, whenever there is a moral issue to be discerned. However, thanks to the habit of acquired synderesis, also a 'routinization' of such judgments occurs. Thus, acquired synderesis facilitates a particular form of moral common sense, namely synesis, which, according to Aquinas, is one of the potential parts of practical reasonalong with eubolia and gnome-rightly able to judge in ordinary cases $\left(S . T h ., \mathrm{II}^{\mathrm{ae}}-\mathrm{II}^{\mathrm{ae}}\right.$, q.51, a.3, a.4; Pellegrini and Ciappei 2015). As a result, the constant natural inclination toward good of innate synderesis may become a potential virtuous practice thanks to its 'acquired' element, which functions as an elicitor of synesis and its judgment in ordinary cases where the discernment follows known paths. Although this discussion about synderesis and practical reason is only embryonic and beyond the scope of the present paper, it could be an interesting avenue for future developments.

\section{Implications for Managers}

The decision maker's moral reasoning has to be continuously overhauled for what Benedict XVI referred to as "ethical blindness caused by the dazzling effect of power and special interests" (Deus Caritas Est, 28, a, 2005). Palazzo et al. (2013) define ethical blindness as "the temporary inability of a decision maker to see the ethical dimension of a decision at stake" (p. 325), due to the rational incapacity of accessing moral principles that are naturally innate. This is particularly relevant in business contexts, where economic, financial, and political interests frequently stimulate managers' rational insensitivity to ethical dilemmas (Groves et al. 2008; Tenbrunsel and Smith-Crowe 2008). As previously stated, the main function of moral reasoning refers to rationalize, reexamine, and justify decision makers' moral judgment (Buchholz and Rosenthal 2005). Actually, managers' rational decision making may sometimes be excessively characterized by a consequential and preference-based attitude that pursues the maximization of individual preferences. Moreover, an excessive reliance on utilitarian reasoning about individual benefits may incline decision makers toward consequentialism aimed at outcome-based judgment (Kim et al. 2009). As a result, consequentialist decision making may induce managers to Machiavellianism, defined as "amoral in the sense that the end, which is usually winning, is sufficient justification for the means" (Miesing and Preble 1985, p. 467). Hence, managers showing high Machiavellianism may pursue objectives by neglecting 
intuitive moral judgments on behalf of unethical tactics and strategies. Consequently, the deliberative sub-process of rational justification present in moral reasoning may deviate from managers' intuitive moral judgments that previously resulted from moral intuition.

The theoretical insights proposed in this paper seem to be relevant in the modern debate related to the reflective practice of ethical reasoning, particularly analyzed in managerial education and management development literature (Small and Cullen 1995). The traditional framework of 'reflective thinking' generally accepted in pertinent literature (Schon 1983), mainly focuses on the rational aspects of human cognitive processes. The accent has been prevailingly placed on managers' awareness and perception of a particular issue, which, in moral terms, represents the first component of Rest's rationalist framework (1986) of ethical decision making (moral awareness). Traditionally, management development programs provide reflective actions such as 'critical reflection,' 'reframing,' and 'unlearning/relearning' activities, through which the educational development of decision makers is improved (Small and Cullen 1995). In this context, moral issues should also represent elements upon which the decision maker has to reflect. Precisely, one of the main 'action points' that our model would like to stimulate refers to the 'rediscovery' of intuition and intuitive moral judgments when reflecting upon moral issues. In this way, the decision maker will reflect and deliberate not only on the moral judgment resulting from the reasoning process, but also on the spontaneous intuitive moral judgment resulting from the moral intuition phase. The scholastic concept of synderesis actually serves a crucial function in this process. This role of synderesis becomes significant when managers, for example, focus on economic evaluations, such as in cost/ benefit analysis. In such circumstances, moral reasoning risks being misled by immoral judgments that result in unethical decision making. Hence, one of the main criticalities of ethical decision making refers to managers' misled moral reasoning that may supersede synderesis, producing in this way both unethical judgments and behaviors.

As a result of the above considerations, a 'rediscovery' of the idea of moral intuition allows managers to reflect on and re-think what their unconscious instinctual response was, and hopefully to 're-calibrate' their judgments on ethical dilemmas. In this way, the effectiveness of the whole ethical decision-making process should be increased.

\section{Conclusion}

The traditional rationalist framework of ethical decision making has been challenged by recent psychological and managerial literature, which stresses the importance of unconscious elements of decision makers' cognition, such as intuition and emotions. Building on the recent social intuitionist perspective, our discussion led us to interpret moral intuition as an antecedent of the ethical decisionmaking process, to be blended with the traditional moral reasoning or the deliberative and intentional process. Furthermore, we use the scholastic framework to enlarge the virtue ethics approaches. Particularly, the scholastic concept of synderesis, thanks to its dual nature, allowed us to integrate the innate ability of moral intuition with moral reasoning in the ethical decision-making framework.

We recognize that our paper suffers from some limitations, mostly because our considerations and propositions are purely theoretical and not supported by empirical evidence. For example, an experimental setting could be useful to empirically test the assumptions that moral intuition precedes the stages of the ethical decision-making framework. Concerning future researches, it would be interesting to apply the whole socio-intuitionist framework (Haidt 2001) in a managerial context, thus analyzing how social persuasion and social influence link the impact on the ethical decision-making process. Furthermore, a relevant issue that has not received appropriate consideration is what happens when the two cognitive systems of human decision making-Systems 1 and 2-contrast and how the resulting conflicts may be handled by decision makers. Particularly, relevant attention should be given to the role emotions have whenever they are in contrast to individual moral reasoning. Another interesting future direction for this work is using our conceptualization of ethical decision making in the context of entrepreneurship personality traits (Rauch and Frese 2007). Particularly, some features of successful entrepreneurs are innate while others are achieved thanks to training and experience. Thus, our model may be employed in this field of research in order to better understand how moral intuition is related to entrepreneurial performance.

\section{References}

Agnihotri, R., Rapp, A., Kothandaraman, P., \& Singh, R. K. (2012). An emotion-based model of salesperson ethical behaviors. Journal of Business Ethics, 109(2), 243-257.

Aquinas, T. (1947). Summa theologica (Fathers of the English Dominican Province, Trans.). New York: Benzinger Press.

Aquinas, T. (1972). Quaestiones disputatae de veritate, Sancti Thomae de Aquino Opera Omnia (Vol. 22). Rome: Editio Leonina.

Aquinas, T. (2000). Scriptum super Libros Sententiarum (II). Bologna: Edizioni Studio Domenicano.

Aristotle. (1998). Nicomachean ethics (W. D. Ross, Trans.). Oxford: Oxford University Press.

Arjoon, S. (2008). Reconciling situational social psychology with virtue ethics. International Journal of Management Reviews, 10(3), 221-243. 
Arjoon, S. (2010). Aristotelian-Thomistic virtue ethics, emotional intelligence and decision-making. Advances in Management, $3(4), 7-13$.

Bastons, M. (2008). The role of virtues in the framing of decisions. Journal of Business Ethics, 78(3), 389-400.

Benedict XVI. (2005). Deus Caritas Est. Vatican City: Libreria Editrice Vaticana.

Benedict XVI. (2007). On conscience. San Francisco: Ignatius Press.

Bonaventure, S. (1889). Commentaria in quatuor libros sententiarum Magistri Petri Lombardi, Tom 1. In P. P. Gollegii a S. Bonaventura (Eds.), Quaracchi: Typographia Collegii S. Bonaventurae.

Bonaventure, S. (1956). Itinerarium Mentis in Deum. In Philotheus Boehner, O. F. M (Ed.), Saint Bonaventure: The Franciscan Institute, Saint Bonaventure University.

Buchholz, R. A., \& Rosenthal, S. B. (2005). The spirit of entrepreneurship and the qualities of moral decision making: Toward a unifying framework. Journal of Business Ethics, 60(3), 307-315.

Carlson, D. S., Kacmar, K. M., \& Wadsworth, L. L. (2009). The impact of moral intensity dimensions on ethical decisionmaking: Assessing the relevance of orientation. Journal of Managerial Issues, 21(4), 534-551.

Celano, A. (2013). The foundation of moral reasoning: The development of the Doctrine of Universal Moral Principles in the works of Thomas Aquinas and his predecessors. Diametros, 38, $1-61$.

Craft, J. L. (2013). A review of the empirical ethical decision-making literature: 2004-2011. Journal of Business Ethics, 117(2), 221-259.

Crossan, M., Mazutis, D., \& Seijts, G. (2013). In search of virtue: The role of virtues, values and character strengths in ethical decision making. Journal of Business Ethics, 113(4), 567-581.

Cushman, F., Young, L., \& Hauser, M. (2006). The role of conscious reasoning and intuition in moral judgment: Testing three principles of harm. Psychological Science, 17(12), 1082-1089.

Dane, E., \& Pratt, M. G. (2007). Exploring intuition and its role in managerial decision making. Academy of Management Review, 32(1), 33-54.

Dane, E., \& Sonenshein, S. (2014). On the role of experience in ethical decision making at work. An ethical expertise perspective. Organizational Psychology Review, 5(1), 74-96.

Das Neves, J. C., \& Melé, D. (2013). Managing ethically cultural diversity: Learning from Thomas Aquinas. Journal of Business Ethics, 116(4), 769-780.

Dierksmeier, C. (2013). Scholastic business ethics: Thomas Aquinas versus William of Ockham. In C. Luetge (Ed.), Handbook of the philosophical foundations of business ethics (pp. 159-178). Heidelberg: Springer.

Dierksmeier, C., \& Celano, A. (2012). Thomas Aquinas on justice as a global virtue in business. Business Ethics Quarterly, 22(2), 247-272.

Epstein, S. (1994). Integration of the cognitive and the psychodynamic unconscious. American Psychologist, 49(8), 709.

Evans, J. S. B. (2008). Dual-processing accounts of reasoning, judgment, and social cognition. Annual Review of Psychology, $59,255-278$.

Ferrell, O., \& Gresham, L. G. (1985). A contingency framework for understanding ethical decision making in marketing. Journal of Marketing, 49, 87-96.

Ford, R. C., \& Richardson, W. D. (1994). Ethical decision making: A review of the empirical literature. Journal of Business Ethics, 13(3), 205-221.
Forlivesi, M. (1993). Conoscenza e affettività: l'incontro con l'essere secondo Giovanni di San Tommaso (Vol. 8). Bologna: Edizioni Studio Domenicano.

Fridja, N. H. (1993). Moods, emotion episodes, and emotions. In M. Lewis \& J. M. Haviland (Eds.), Handbook of emotions (pp. 381-404). New York: Guilford Press.

Gaudine, A., \& Thorne, L. (2001). Emotion and ethical decision-making in organizations. Journal of Business Ethics, 31(2), 175-187.

Gerson, J. (1958). De mystica theologia. In A. Combes (Ed.), Thesaurus Mundi, Lugano.

Gorevan, P. (2000). Aquinas and emotional theory today: Mind-body cognitivism and connaturality. Acta Philosophica, 9(1), 141-151.

Greene, J. D., Sommerville, R. B., Nystrom, L. E., Darley, J. M., \& Cohen, J. D. (2001). An fMRI investigation of emotional engagement in moral judgment. Science, 293(5537), 2105-2108.

Greene, R. A. (1991). Synderesis, the spark of conscience, in the English Renaissance. Journal of the History of Ideas, 52(2), 195-219.

Greene, R. A. (1997). Instinct of nature: Natural law, synderesis, and the moral sense. Journal of the History of Ideas, 58(2), 173-198.

Groves, K., Vance, C., \& Paik, Y. (2008). Linking linear/nonlinear thinking style balance and managerial ethical decision-making. Journal of Business Ethics, 80(2), 305-325.

Haidt, J. (2001). The emotional dog and its rational tail: A social intuitionist approach to moral judgment. Psychological Review, 108(4), 814-834.

Haidt, J. (2003a). The emotional dog does learn new tricks: A reply to Pizarro and Bloom (2003). Psychological Review, 110, 197-198.

Haidt, J. (2003b). The moral emotions. In R. J. Davidson, K. R. Scherer, \& H. H. Goldsmith (Eds.), Handbook of affective sciences (pp. 852-870). Oxford: Oxford University Press.

Haidt, J. (2007). The new synthesis in moral psychology. Science, 316, 998-1002.

Haidt, J., \& Bjorklund, F. (2008). Social intuitionists answer six questions about morality. In W. Sinnott-Armstrong (Ed.), Moral psychology: The cognitive science of morality (Vol. 2, pp. 181-217). Cambridge, MA: MIT Press.

Haidt, J., \& Joseph, C. (2004). Intuitive ethics: How innately prepared intuitions generate culturally variable virtues. Daedalus, 133(4), $55-66$.

Hodgkinson, G. P., Langan-Fox, J., \& Sadler-Smith, E. (2008). Intuition: A fundamental bridging construct in the behavioural sciences. British Journal of Psychology, 99(1), 1-27.

Hunt, S. D., \& Vitell, S. (1986). A general theory of marketing ethics. Journal of Macromarketing, 6(1), 5-16.

Javelet, R. (1961). Intelligence et amour chez les auteurs spirituels du XII ${ }^{\mathrm{e}}$ siècle. Revue d'Ascétique et de Mystique, 37, 273-290.

Jones, T. M. (1991). Ethical decision making by individuals in organizations: An issue-contingent model. Academy of Management Review, 16(2), 366-395.

Kahneman, D. (2003). A perspective on judgment and choice: Mapping bounded rationality. American Psychologist, 58(9), 697-720.

Kahneman, D., \& Frederick, S. (2002). Representativeness revisited: Attribute substitution in intuitive judgement. In T. Gilovich, D. Griffin, \& D. Kahneman (Eds.), Heuristics and biases: The psychology of intuitive judgment (pp. 49-81). Cambridge: Cambridge University Press.

Kant, I. (1785/1959). Foundations of the metaphysics of morals (L.W. Beck, Trans.). Indianapolis: Bobbs-Merrill.

Kant, I. (1790/1914). Critique of judgement (J. H. Bernard, Trans.). London: Macmillan. 
Kärkkäinen, P. (2012). Synderesis in Late Medieval philosophy and the Wittenberg reformers. British Journal for the History of Philosophy, 20(5), 881-901.

Kihlstrom, J. F. (1987). The cognitive unconscious. Science, 237(4821), 1445-1452.

Kihlstrom, J. F., Mulvaney, S., Tobias, B. A., \& Tobis, I. P. (2000). The emotional unconscious. In E. Eich, J. F. Kihlstrom, G. H. Bower, J. P. Forgas, \& P. M. Niedenthal (Eds.), Cognition and emotion (pp. 30-86). New York: Oxford University Press.

Kim, D., Fisher, D., \& McCalman, D. (2009). Modernism, christianity, and business ethics: A worldview perspective. Journal of Business Ethics, 90(1), 115-121.

Kim, J. E., \& Johnson, K. K. (2013). The impact of moral emotions on cause-related marketing campaigns: A cross-cultural examination. Journal of Business Ethics, 112(1), 79-90.

King, P. (1999). Aquinas on the Passions. In S. MacDonald \& E. Stump (Eds.), Aquinas's moral theory (pp. 101-132). Ithaca, NY: Cornell University Press.

Koehn, D. (1995). A role for virtue ethics in the analysis of business practice. Business Ethics Quarterly, 50(3), 533-539.

Kohlberg, L. (1969). Stage and sequence: The cognitive developmental approach to socialization. In D. A. Goslin (Ed.), Handbook of socialization theory and research (pp. 347-380). Chicago: Rand McNally.

Korsgaard, C. M. (2013). Conscience. In J. J. Chambliss (Ed.), Philosophy of education: An encyclopedia (pp. 1-4). Oxon: Routledge.

Langston, D. (1993). The spark of conscience: Bonaventure's view of conscience and synderesis. Franciscan Studies, 53(1), 79-95.

Langston, D. (2011). Medieval theories of conscience. In E. N. Zalta (Ed.). The Stanford encyclopedia of philosophy. Accessed June 13, 2015, from http://plato.stanford.edu/archives/fall2011/ entries/conscience-medieval/.

Lazarus, R. S. (1984). On the primacy of cognition. American Psychologist, 39(2), 124-129.

Lewis, P. V. (1989). Ethical principles for decision makers: A longitudinal survey. Journal of Business Ethics, 8(4), 271-278.

Liebert, E. (2008). The way of discernment: Spiritual practices for decision making. Louisville, KY: Westminster John Knox Press.

Lombard, P. (2007). The sentences book 1: The mystery of the trinity (Giulio Silano, Trans.). Toronto: Pontifical Institute of Mediaeval Studies

Lottin O. (1942). Le rôle de la raison dans la morale AlbertinoThomiste. In Psychologie et morale aux $\mathrm{XII}^{\mathrm{e}}$ et $\mathrm{XIII}^{\mathrm{e}}$ siècles, Abbaye du Mont César, Duclot, Louvain, Gembloux

Lurie, Y. (2004). Humanizing business through emotions: On the role of emotions in ethics. Journal of Business Ethics, 49(1), 1-11.

Luther, M. (1964). Dictata super Psalterium, 1513-1516. In D. Martin Luthers Werke (Ed.) (pp. 410-441) Kritische Gesamtausgabe, Graz

Marquardt, N., \& Hoeger, R. (2009). The effect of implicit moral attitudes on managerial decision-making: An implicit social cognition approach. Journal of Business Ethics, 85(2), 157-171.

Melé, D. (2005). Ethical education in accounting: Integrating rules, values and virtues. Journal of Business Ethics, 57(1), 97-109.

Melé, D. (2010). Practical wisdom in managerial decision making. Journal of Management Development, 29(7), 637-645.

Melé, D. (2016). Re-thinking capitalism: What we can learn from scholasticism? Journal of Business Ethics, 133, 293-304. doi:10. 1007/s10551-014-2368-4.

Metcalfe, J., \& Mischel, W. (1999). A hot/cool-system analysis of delay of gratification: Dynamics of willpower. Psychological Review, 106(1), 3-19.

Miesing, P., \& Preble, J. F. (1985). A comparison of five business philosophies. Journal of Business Ethics, 4(6), 465-476.
Morales-Sánchez, R., \& Cabello-Medina, C. (2013). The role of four universal moral competencies in ethical decision-making. Journal of Business Ethics, 116(4), 717-734.

O'Fallon, M. J., \& Butterfield, K. D. (2005). A review of the empirical ethical decision-making literature: 1996-2003. Journal of Business Ethics, 59(4), 375-413.

Ojakangas, M. (2013). The voice of conscience: A political genealogy of western ethical experience. New York: Bloomsbury Publishing.

Palazzo, G., Krings, F., \& Hoffrage, U. (2013). Ethical blindness. Journal of Business Ethics, 109(3), 323-338.

Pellegrini, M. M., \& Ciappei, C. (2015). Ethical judgment and radical business changes: The role of entrepreneurial perspicacity. Journal of Business Ethics, 128(4), 769-788.

Peyligk, J. (1499). Philosophie naturalis compendium. Leipzig: Melchior Lotter.

Philip the Chancellor. (1985). Philippi Cancellarii Parisiensis Summa de Bono. In N. Wicki (Ed.), Corpus Philosophorum Medii Aevi: Opera philosophica mediae aetatis selecta, II. Bern: Francke.

Poinsot, J. (1632/1985). Tractatus de Signis: The semiotic of John Poinsot. Berkeley: University of California Press.

Potts, T. C. (1980). Conscience in medieval philosophy. New York: Cambridge University Press.

Provis, C. (2015). Intuition, analysis and reflection in business ethics. Journal of Business Ethics. doi:10.1007/s10551-015-2688-z.

Rauch, A., \& Frese, M. (2007). Born to be an entrepreneur? Revisiting the personality approach to entrepreneurship. In J. R. Baum, M. Frese, \& R. A. Baron (Eds.), The psychology of entrepreneurship (pp. 41-65). Mahwah, NJ: Erlbaum.

Rest, J. R. (1986). Moral development: Advances in research and theory. New York: Praeger.

Rest, J. R., \& Narváez, D. (1994). Moral development in the professions: Psychology and applied ethics. Hillsdale, NJ: Lawrence Erlbaum.

Schon, D. A. (1983). The reflective practitioner: How professionals think in action. New York: Basic Books.

Sinclair, M., \& Ashkanasy, N. M. (2005). Intuition myth or a decision-making tool? Management Learning, 36(3), 353-370.

Small, M. W., \& Cullen, J. L. (1995). Socialization of business practitioners: Learning to reflect on current business practices. Journal of Business Ethics, 14(8), 695-701.

Smith, R. J. (1998). Conscience and catholicism: The nature and function of conscience in contemporary roman catholic moral theology. Lanham, MD: University Press of America.

Sonenshein, S. (2007). The role of construction, intuition, and justification in responding to ethical issues at work: The sensemaking-intuition model. Academy of Management Review, 32(4), 1022-1040.

Stanovich, K. E. (2008). Distinguishing the reflective, algorithmic, and autonomous minds: Is it time for a tri-process theory? In J. Evans \& K. Frankish (Eds.), In two minds: Dual processes and beyond (pp. 55-88). Oxford: Oxford University Press.

Stanovich, K. E., \& West, R. F. (2000). Advancing the rationality debate. Behavioral and Brain Sciences, 23(5), 701-717.

Tenbrunsel, A. E., \& Smith-Crowe, K. (2008). Ethical decision making: Where we've been and where we're going. Academy of Management Annals, 2(1), 545-607.

Treviño, L. K. (1986). Ethical decision making in organizations: A person-situation interactionist model. Academy of Management Review, 11(3), 601-617.

Treviño, L. K., Weaver, G. R., \& Reynolds, S. J. (2006). Behavioral ethics in organizations: A review. Journal of Management, 32(6), 951-990.

Tversky, A., \& Kahneman, D. (1986). Rational choice and the framing of decisions. Journal of Business, 59(4), 251-278. 
Verplaetse, J. (2009). Localizing the moral sense: Neuroscience and the search for the cerebral seat of morality, 1800-1930. New York: Springer.

Wang, G., \& Hackett, R. D. (2015). Conceptualization and measurement of virtuous leadership: Doing well by doing good. Journal of Business Ethics. doi:10.1007/s10551-015-2560-1doi:.

Weaver, G. R., Reynolds, S. J., \& Brown, M. E. (2014). Moral intuition connecting current knowledge to future organizational research and practice. Journal of Management, 40(1), $100-129$.
Whitaker, B. G., \& Godwin, L. N. (2013). The antecedents of moral imagination in the workplace: A social cognitive theory perspective. Journal of Business Ethics, 114(1), 61-73.

Woiceshyn, J. (2011). A model for ethical decision making in business: Reasoning, intuition, and rational moral principles. Journal of Business Ethics, 104(3), 311-323.

Zajonc, R. B. (1984). On the primacy of affect. American Psychologist, 39(2), 117-123.

Zhong, C. B. (2011). The ethical dangers of deliberative decision making. Administrative Science Quarterly, 56(1), 1-25. 